KAPLAN, C. \& VAlentine, R. C. (1959). J. gen. Microbiol. 20, 612-619

\title{
The Infectivity of Purified and Partially Purified Preparations of Vaccinia and Cowpox Viruses
}

\author{
By C. KAPLAN \\ Lister Institute of Preventive Medicine, Elstree, Hertfordshire \\ AND R. C. VALENTINE \\ National Institute for Medical Research, Mill Hill, London, N.W. 7
}

\begin{abstract}
SUMMARY: Twenty-three preparations of vaccinia virus and 5 of cowpox virus were examined by electron microscopy of spray droplets and by infectivity titrations at various stages of purification. Extraction of virus-containing tissues with a fluorocarbon compound was a useful early step in purification, but preparations of the highest purity were obtained by flocculation of the virus with $\mathrm{M}-\mathrm{NaCl}$. The average ratio of total particle count to infectivity for the vaccinia virus preparations was 12. The lowest observed ratio based on reliable particle counts was $3 \cdot 4$.
\end{abstract}

During inactivation of vaccinia virus, a very small, but constant, fraction of infectivity was observed to survive extremely high doses of gamma-radiation. In order to assess the likelihood of multiple reactivation being responsible for this persistence, it was necessary to know the ratio of infective units to total particle count in the type of virus preparation being irradiated. The two groups of published figures for vaccinia virus are not in close agreement, so several preparations of vaccinia virus, and a few of cowpox virus, were counted by electron microscopy and titrated for infectivity. The influence of various methods of purification on the preparations was also studied.

\section{METHODS}

Viruses. The vaccinia virus strains were all sublines of the Lister Institute vaccine strain. The rabbit dermal virus (RV) was a homogeneous line (Amies, 1938) in its 80th skin passage. Chick embryo adapted virus (LC) had been passed from 13 to 16 times in the chick embryo chorioallantois. Tissue culture virus $(\mathrm{T})$ was taken from the first five batches of virus grown for smallpox vaccine preparation. This virus was a first passage of bacteriologically sterile RV in trypsinized chick embryo cells. The cowpox virus was a strain lyophilized in 1939 and recently cultivated. Its history is unknown, but it produced typical haemorrhagic lesions in the chick embryo chorioallantois after 3 days of incubation.

Diluent. All extractions and dilutions were made in McIlvaine's phosphate +

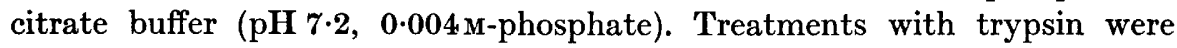
done with Armour's crystalline, salt-free product.

Extractions were made by mechanical disruption of the virus-infected tissues in a Servall 'Omnimix' homogenizer at 14,000 rev. $/ \mathrm{min}$. for $5 \mathrm{~min}$., with an ice-bath round the stainless steel vessel. Trifluorotrichloroethane (Gessler, 
Bender \& Parkinson, 1956) was used in some of the extraction and purification procedures; it was obtained from Imperial Chemical Industries Ltd. as 'Arcton 63'.

Nitrogen was estimated by a micro-Kjeldahl method.

Methods of purification used are described under Results. The initial step in all the preparations was horizontal centrifugation of the extracts at $1500 \mathrm{~g}$ for $10 \mathrm{~min}$., the virus-containing supernatant fluids being kept for further treatment.

Infectivity titrations were by pock count on the chick embryo chorioallantois. Membranes were prepared and inoculated by the method of Westwood, Phipps \& Boulter (1957). Infectivity titres (I) are expressed as infectious units/millilitre (i.u./ml.).

Total particle counts $(T)$ were made with the electron microscope by the spray drop method of Williams \& Backus (1949), which was fully described by Luria, Williams \& Backus (1951). The polystyrene latex spheres used as indicator particles were generously given by The Dow Chemical Corporation, Midland, Michigan, U.S.A., from their batch no. LS-055-A. The absolute count of these particles/ml. suspension was determined from its dry weight, the density of the latex $(1.05 \mathrm{~g} . / \mathrm{ml}$.) and their diameter. This latter measurement was made in terms of an electron transparent aluminium replica of a standard grating on which the particles were mounted. An independent determination was also made in terms of the diameter of the particles in the original batch of latex (580-G) which was well established as $0 \cdot 26 \mu$, the mean of many different independent determinations made in various laboratories reported by Gerould (1950). Both methods gave the diameter of $0 \cdot 16 \mu$ for the latex used. This differs considerably from the figure supplied by the manufacturers $(0.19 \mu)$ which was measured on a nitrocellulose replica (Bradford \& Vanderhoff, 1955). As nitrocellulose can contract considerably when the replica is mounted on its support we have preferred our figure of $0 \cdot 16 \mu$. The use of the larger figure would decrease the particle counts cited below by a factor of $0 \cdot 6$.

A sufficient number of the latex and virus particles was counted in each preparation to give a standard error of $c .10 \%$ in their ratio (this requires a count of 200 particles of each kind when the ratio is one).

\section{RESULTS}

\section{Influence of 'Arcton 63' on virus yield and purity}

The use of 'Arcton 63' in the preliminary extraction of the virus was suggested by Gessler et al. (1956). The efficiency of repeated extraction in Arcton 63 was tested by extracting several rabbit dermal pulps in $20 \mathrm{ml}$. buffer with $1 \mathrm{ml}$. Arcton/g. of pulp. The supernatant of the first extraction was kept and the Arcton-containing deposit was re-extracted after the addition of $20 \mathrm{ml}$. of fresh buffer. The second extraction may set free as much as $15 \%$ of the first yield (Table 1). The average ratio of particles to infective units in the first extractions was 15 . 
The efficiency of Arcton 63 as a first step in purification was tested by extracting equal weights of dermal pulp in buffer and in buffer + Arcton 63 ( $1 \mathrm{ml} . / \mathrm{g}$. pulp). Homogenizing with Arcton 63 reduced the total nitrogen content of the centrifuged extract by about $30 \%$ (Table 2). Compared with the opaque, milky supernatants of the buffer extracts, the Arcton extracts were translucent. The titres of the extracts were the same whether Arcton 63 was used or not. However, the removal of as much as $30 \%$ of impurity during the extraction, without measurable loss of virus, is a very useful start in a purification process.

Table 1. Efficiency of repeated extraction in Arcton 63

\begin{tabular}{|c|c|c|c|c|c|}
\hline $\begin{array}{l}\text { Prep. } \\
\text { no. }\end{array}$ & $\begin{array}{c}I_{1} \\
\text { 1st extraction }\end{array}$ & $\frac{I_{2}}{\text { 2nd extraction }}$ & $I_{2} / I_{1}$ & $\begin{array}{c}T \\
\text { 1st extraction }\end{array}$ & $T / I_{1}$ \\
\hline 1 & $8.5 \times 10^{9}$ & $1.3 \times 10^{9}$ & $0 \cdot 15$ & $8.9 \times 10^{10}$ & $10 \cdot 5$ \\
\hline 2 & $3.3 \times 10^{9}$ & $3.6 \times 10^{8}$ & $0 \cdot 11$ & $6 \cdot 2 \times 10^{10}$ & $18 \cdot 8$ \\
\hline $\mathbf{3}$ & $4 \cdot 36 \times 10^{9}$ & $2 \cdot 75 \times 10^{8}$ & 0.06 & $7 \cdot 2 \times 10^{10}$ & $16 \cdot 5$ \\
\hline 4 & $2.96 \times 10^{9}$ & $4.75 \times 10^{8}$ & $\mathbf{0} \cdot 16$ & $5.0 \times 10^{10}$ & $16 \cdot 9$ \\
\hline
\end{tabular}

Table 2. Influence of Arcton 63 on virus yield and purity

\begin{tabular}{|c|c|c|c|}
\hline Pulp no. & Extracted in & $I$ & $\begin{array}{c}\mathbf{N}_{2} \\
\text { (mg./ml.) }\end{array}$ \\
\hline 70 & $\begin{array}{l}\text { Buffer } \\
\text { Buffer + Arcton }\end{array}$ & $\begin{array}{l}2.5 \times 10^{9} \\
2.5 \times 10^{9}\end{array}$ & $\begin{array}{l}0.75 \\
0.52\end{array}$ \\
\hline 71 & $\begin{array}{l}\text { Buffer } \\
\text { Buffer + Arcton }\end{array}$ & $\begin{array}{l}3.6 \times 10^{9} \\
3.2 \times 10^{9}\end{array}$ & $\begin{array}{l}0 \cdot 66 \\
0 \cdot 43\end{array}$ \\
\hline 73 & $\begin{array}{l}\text { Buffer } \\
\text { Buffer + Arcton }\end{array}$ & $\begin{array}{l}7.0 \times 10^{9} \\
6.0 \times 10^{9}\end{array}$ & $\begin{array}{l}1.08 \\
0 \cdot 71\end{array}$ \\
\hline
\end{tabular}

\section{Purification of vaccinia and corwpox viruses by various methods}

Dermal virus. The virus was extracted from dermal pulp in buffer, and after initial centrifugation, purification was undertaken by several methods (Table 3). RV80/a, b and c were dealt with by one, two and three cycles, respectively, of differential centrifugation. A cycle consisted of sedimentation of the virus in an angle rotor ( $28^{\circ}$ from vertical) at $2600 \mathrm{~g}$ for $60 \mathrm{~min}$., and, after resuspension in fresh buffer by stirring and gentle pipetting with a wide bore (1.5-2.0 mm.) Pasteur pipette, deposition of debris by horizontal centrifugation at $c .1500 \mathrm{~g}$ for $5 \mathrm{~min}$. At the final resuspension, the preparation was concentrated tenfold or more. Table 3 records the particle counts and infectivities of the various preparations. The vaccinated area of skin of RV 80/a was inadvertently swabbed with $20 \%(\mathrm{v} / \mathrm{v})$ ethanol in water immediately before harvesting, instead of with $1 \%$ 'Hibitane'. McClean (1945) showed that ethanol destroyed the infectivity of vaccinia virus, and the high ratio of particles to infectivity found in this preparation may well be a reflexion of this. In the other two preparations the ratio was less than 10.

Plate 1, fig. 1, shows the fuzzy appearance of the virus which indicates the presence of soluble impurities in the preparation. Dawson \& McFarlane (1948) 
produced very pure virus by flocculating their preparations with $\mathrm{M}-\mathrm{NaCl}$, washing, and then resuspending the virus by ultrasonic vibration. Section $b$ of Table 3 displays the results obtained when the clarified supernatant fluid of a dermal pulp extract was divided into four portions of equal volume, two of which were then salt flocculated. After this treatment the preparations contained far less extraneous material as judged from electron micrographs and the particles were more sharply defined (Pl. 1, fig. 2). Although (according to Dawson \& McFarlane, 1948) about $40 \%$ of the virus is lost in the supernatant after salt flocculation, not only is the infectivity of the remaining virus undiminished, but there is a suggestion that it is increased.

Table 3. Influence of purification procedures on infectivity and particle count of rabbit dermal vaccinia virus

\begin{tabular}{|c|c|c|c|c|}
\hline Prep. no. & Treatment & $\boldsymbol{I}$ & $T$ & $T / I$ \\
\hline $\begin{array}{l}\text { RV 80/a } \\
\text { RV 80/b } \\
\text { RV 80/c }\end{array}$ & $\begin{array}{l}\text { (Eth.) d.c. } \\
\text { d.c. } \times 2 \\
\text { d.c. } \times 3\end{array}$ & $\begin{array}{l}4.5 \times 10^{8}( \pm 80 \%) \\
1.4 \times 10^{10}( \pm 31 \%) \\
2.7 \times 10^{10}( \pm 19 \%)\end{array}$ & $\begin{array}{l}5.8 \times 10^{10} \\
1.1 \times 10^{11} \\
1.9 \times 10^{11}\end{array}$ & $\begin{array}{r}129( \pm 81 \%) \\
7 \cdot 8( \pm 33 \%) \\
7 \cdot 0( \pm 22 \%)\end{array}$ \\
\hline $\begin{array}{l}\text { b } 1 \\
\text { A2 } \\
\text { B1 } \\
\text { B2 }\end{array}$ & $\begin{array}{l}\text { A; d.c.; NaCl; u.s. } \\
\text { A; d.c.; u.s. } \\
\text { B; d.c.; NaCl; u.s. } \\
\text { B; d.c.; u.s. }\end{array}$ & 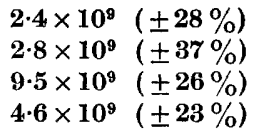 & $\begin{array}{l}\text { c. } 3 \times 10^{9} \\
2.6 \times 10^{10} \\
4.2 \times 10^{10} \\
4.9 \times 10^{10}\end{array}$ & $\begin{aligned} \text { c. } 1 \cdot 2 \\
9 \cdot 3( \pm 39 \%) \\
4 \cdot 4( \pm 28 \%) \\
10 \cdot 7( \pm 25 \%)\end{aligned}$ \\
\hline
\end{tabular}

Eth. = swabbed with $20 \%(v / v)$ ethanol in water; d.c. = differential centrifugation; $\mathrm{A}=$ extracted with Arcton 63; $\mathrm{B}=$ extracted with buffer; $\mathrm{NaCl}=$ flocculated with $\mathrm{M}-\mathrm{NaCl} ;$ u.s. = resuspended by ultrasonic vibration.

Table 4. Influence of trypsin on the infectivity of chick embryo vaccinia virus

\begin{tabular}{lllll} 
Prep. no. & Treatment & \multicolumn{1}{c}{$I$} & $T$ & $T / I$ \\
L13 & d.c. & $2 \cdot 4 \times 10^{9}( \pm 29 \%)$ & $4 \cdot 4 \times 10^{10}$ & $18 \cdot 4( \pm 31 \%)$ \\
L14 i & d.c. & $7 \cdot 4 \times 10^{9}( \pm 58 \%)$ & $3 \cdot 5 \times 10^{10}$ & $4 \cdot 7( \pm 59 \%)$ \\
L14 ii & d.c. & $7 \cdot 3 \times 10^{9}( \pm 14 \%)$ & $2 \cdot 4 \times 10^{10}$ & $\mathbf{3 \cdot 4}( \pm 17 \%)$ \\
L15B & d.c.; B & $1 \cdot 1 \times 10^{10}( \pm 35 \%)$ & $1 \cdot 6 \times 10^{11}$ & $14 \cdot 2( \pm 36 \%)$ \\
L15E & d.c.; E & $8 \cdot 0 \times 10^{9}( \pm 6 \%)$ & $1 \cdot 8 \times 10^{11}$ & $\mathbf{2 2 . 5}( \pm 12 \%)$ \\
L16 B & d.c.; B & $1 \cdot 4 \times 10^{10}( \pm 43 \%)$ & $1 \cdot 4 \times 10^{11}$ & $10 \cdot 0( \pm 45 \%)$ \\
L16E & d.c.; E & $2 \cdot 1 \times 10^{10}( \pm 31 \%)$ & $2 \cdot 6 \times 10^{11}$ & $12 \cdot 4( \pm 33 \%)$
\end{tabular}

d.c. = differential centrifugation; $B=$ incubation with buffer for 30 min. at $37^{\circ}$; $\mathrm{E}=$ incubation with $0.025 \%$ trypsin for $30 \mathrm{~min}$. at $37^{\circ}$.

Chick embryo adapted virus. Table 4 shows the results obtained by purification of chick embryo virus by centrifugation and a combination of centrifugation and enzymic methods. Chick embryo adapted virus cannot be flocculated by $\mathrm{M}-\mathrm{NaCl}$. The reason for this is unknown. Protein impurities may, however, be sensibly diminished by treatment with trypsin (Smadel \& Wall, 1937). The results of these experiments suggest that trypsin is not harmful to the virus.

Tissue culture virus. The harvested cultures were disrupted in the Servall 'Omnimix'. Cell debris and virus were then sedimented in an angle centrifuge at $2600 \mathrm{~g}$ for $60 \mathrm{~min}$. and the deposit resuspended in fresh buffer to give a volume concentration of about 20 -fold. To overcome clumping of virus in the 
cell debris the suspension was homogenized for $30 \mathrm{sec}$. in the 'Omnimix' before titration. No other procedure was used to purify the virus. Pl. 1, fig. 3 , shows the degree of contamination with cellular components compared with that of a rabbit virus preparation given one cycle of differential centrifugation (Pl. 1, fig. 4). The ratio of particles to infectivity (Table 5) does not differ greatly from that of partially purified rabbit dermal virus (Table 1).

\section{Table 5. Particle count/infectivity ratio of tissue} culture vaccinia virus

$\begin{array}{cccc}\text { Prep. no. } & I & T & T / I \\ \text { T1 } & 1.0 \times 10^{10}( \pm 25 \%) & 1.25 \times 10^{11} & 12.5( \pm 27 \%) \\ \text { T2 } & 8.9 \times 10^{9}( \pm 16 \%) & 1 \cdot 3 \times 10^{11} & 14.6( \pm 19 \%) \\ \text { T3 } & 7 \cdot 1 \times 10^{9}( \pm 59 \%) & 8 \cdot 1 \times 10^{10} & 11 \cdot 4( \pm 60 \%) \\ \text { T4 } & 8 \cdot 5 \times 10^{\circ}( \pm 16 \%) & 9 \cdot 3 \times 10^{10} & 10.9( \pm 19 \%) \\ \text { T5 } & 7.0 \times 10^{9}( \pm 9 \%) & 1 \cdot 3 \times 10^{11} & 18.6( \pm 13 \%)\end{array}$

Cowpox virus. A few preparations only of this virus were examined. The results (Table 6) are in general agreement with those of Dumbell, Downie \& Valentine (1957) as far as the high ratio of particles to pock-producing infective units is concerned, but the number of preparations studied was too small to allow further comment.

Table 6. Influence of trypsin on cowpox virus yield and infectivity

\begin{tabular}{|c|c|c|c|c|c|}
\hline Prep. no. & Treatment & $\boldsymbol{I}$ & $\boldsymbol{T}$ & & $T / I$ \\
\hline C3 & d.c. & $3 \cdot 1 \times 10^{9}( \pm 24 \%)$ & $4.7 \times 10^{11}$ & 150 & $( \pm 26 \%)$ \\
\hline $\mathrm{C} 4 \mathrm{~B}$ & d.c.; B & $3.5 \times 10^{9}( \pm 36 \%)$ & $1.9 \times 10^{11}$ & $\mathbf{5 4} \cdot 5$ & $( \pm 38 \%)$ \\
\hline C4E & d.c.; E & $2.4 \times 10^{9}( \pm 17 \%)$ & $1.9 \times 10^{11}$ & 78 & $( \pm 20 \%)$ \\
\hline C5B & d.c.; B & $2.6 \times 10^{9}( \pm 17 \%)$ & $1.9 \times 10^{11}$ & 72 & $( \pm 20 \%)$ \\
\hline C5E & d.c.; E & $1.3 \times 10^{9}( \pm 38 \%)$ & $1.6 \times 10^{11}$ & 127 & $( \pm 39 \%)$ \\
\hline
\end{tabular}

d.c. $=$ differential centrifugation; $B=$ incubation with buffer for $30 \mathrm{~min}$. at $37^{\circ}$; $\mathbf{E}=$ incubation with $0.025 \%$ trypsin for $30 \mathrm{~min}$. at $37^{\circ}$.

\section{DISCUSSION}

Judged by their electron microscope appearances, preparations purified by salt flocculation contained less extraneous material than those in which salt flocculation was not used. Arcton 63 extraction (Gessler et al. 1956) is a useful addition to the methods available for purification of vaccinia virus, but as Epstein (1958) showed, even five successive extractions with Arcton 63 may not entirely remove non-virus material. He found free deoxyribonucleic acid in ultracentrifugates of vaccinia virus extracted from infected chorioallantoic membranes. The appearance of the virus in our electron micrographs (Pl. 1, figs. 1, 2) suggests that flocculation with $\mathrm{M}-\mathrm{NaCl}$ is always a worthwhile final step in the procedure when highly purified vaccinia virus is wanted. The virus yields shown in Table 1 indicate that more than two extractions of virus-containing material with Arcton 63 are not worthwhile.

The ratios of almost unity of total to infective vaccinia virus particles 
$(T / I)$ found by Overman \& Tamm (1956) are considerably lower than those reported here. However, we suspect that their method of estimating the total count may well have given too low a figure because some virus was not picked up on the supports and some was obscured by debris. In view of such criticisms, an attempt was recently made to demonstrate the accuracy of the sedimentation technique (Sharp \& Overman, 1958). It appears that the method does give a reliable estimate of the number of vaccinia particles in a sample provided this has been adequately diluted. However, the dilutions used by Overman \& Tamm (1956) when making their counts were lower than those now found to be necessary. This subsequent work confirms the opinion that the counts recorded by Overman \& Tamm were in error. The figures of Dumbell et al. (1957) are more in accord with ours. However, despite a close correspondence between their $T / I$ ratios and ours for cowpox virus, based on the pock count titre, their vaccinia virus $T / I$ ratios are somewhat higher than ours; excluding their trypsin-treated preparations, their ratio was 18. The average for all our preparations was 12 and in several of these the pock count, for reasons connected with the preparation of the membranes, was certainly too low. This suggests that the technique of chorioallantoic membrane inoculation of Dumbell et al. is probably less sensitive than that of Westwood et al. (1957) which we used.

Unlike Dumbell et al. (1957), we failed to find any substantial deleterious effect of trypsin on the infectivity of vaccinia virus. However, the results obtained with cowpox virus do not exclude an inactivating effect of trypsin on the virus. The inactivation Dumbell et al. observed could have been due to their use of 'Difco' trypsin 1/250. Pirie (1935) showed that dried pancreas contains substances soluble in light petroleum which can destroy the infectivity of vaccinia and some other viruses. One of us (C. K.) found that 'Difco' trypsin (a preparation of dried pig pancreas) behaved like Pirie's preparations, and that thorough extraction of this material with petroleum ether removed the virucidal substances without significantly altering its tryptic activity.

There was little, if any, inactivation of vaccinia virus by the methods of purification used in this work. On several occasions when the clarified extracts were titrated as well as the final virus suspensions, recovery was in the region of $90 \%$. Nevertheless, the fact that ratios of total particle count to infectivity reliably close to unity were not obtained might be due to either the presence in all fresh preparations of 'incomplete' virus, or to the use of titration methods that are less than $100 \%$ efficient. Unlike the influenza viruses, vaccinia virus has no known attribute other than infectivity by which it may be assayed biologically. In the absence of any evidence in its favour, the 'incomplete' virus hypothesis will not be discussed. It remains, therefore, to consider possible causes of inefficiency in the available titration methods.

The pock-counting method of titrating vaccinia virus is probably the most sensitive one in general use. It has, however, the inherent limitation imposed by the slow rate of adsorption of virus to sensitive cells. This is due directly to the size of the virus: being relatively large it diffuses very slowly and therefore it is improbable that all the infectious particles in a given dose of 
virus will meet susceptible cells before appreciable loss of infectivity has occurred at $37^{\circ}$. Boulter (1957) showed that in dilute McIlvaine buffer (the diluent used in these experiments) approximately a quarter of the virus was inactivated after $2 \mathrm{hr}$. incubation at $37^{\circ}$. Because of its size, maximum adsorption of the virus may be expected to take longer than $2 \mathrm{hr}$., with a corresponding increase in the proportion inactivated. Investigation of a medium which protects vaccinia virus from heat inactivation might thus give a lower ratio of total to infectious particles than that obtained with suspensions in dilute buffer.

Even when the hazard of heat-inactivation is removed, the chorionic cells of the chorioallantois may not, however, be equally susceptible to the virus either because of natural factors or because of varying degrees of invisible trauma suffered by the membrane during the dropping procedure. $T / I$ ratios close to but significantly greater than unity are therefore to be expected even if virus preparations contain no inactive particles.

\section{REFERENCES}

Amres, C. R. (1938). The production of homogeneous suspensions of vaccinia elementary bodies and the histology of the associated skin lesions. J. Path. Bact. 47, 205.

Boulter, E. A. (1957). The titration of vaccinial neutralizing antibody on chorioallantoic membranes. J. Hyg., Camb. 55, 502.

BradFord, E. B. \& VANDERHoFF, J. W. (1955). Electron microscopy of monodisperse latexes. J. appl. Phys. 26, 864.

Dawson, I. M. \& McFarlane, A. S. (1948). Structure of an animal virus. Nature, Lond. 161, 464.

Dumbeli, K. R., Downie, A. W. \& Valentine, R. C. (1957). The ratio of the number of virus particles to infective titer of cowpox and vaccinia virus suspensions. Virology, 4, 467.

EPSTEIN, M. A. (1958). An investigation into the purifying effect of a fluorocarbon on vaccinia virus. Brit. J. exp. Path. 39, 436.

Gerould, C. H. (1950). Comments on the use of latex spheres as size standards in electron microscopy. J. appl. Phys. 21, 183.

Gessler, A. E., Bender, C. E. \& Parkinson, M. C. (1956). A new and rapid method for isolating viruses by selective fluorocarbon deproteinization. Trans. N.Y. Acad. Sci. 18, 701.

Luria, S. E., Williams, R. C. \& Backus, R. C. (1951). Electron micrographic counts of bacteriophage particles. J. Bact. 61, 179.

McCleAN, D. (1945). The antigenicity of vaccinia virus inactivated with alcohol. J. Path. Bact. 57, 261.

Overman, J. R. \& TAMm, I. (1956). Equivalence between vaccinia particles counted by electron microscopy and infectious units of the virus. Proc. Soc. exp. Biol., N.Y. $92,806$.

Pirie, A. (1935). The effect of extracts of pancreas on different viruses. Brit. $J$. exp. Path. 16, 497.

Sharp, D. G. \& Overman, J. R. (1958). Enumeration of vaccinia virus particles in crude extracts of infected tissues by electron microscopy. Proc. Soc. exp. Biol., N.Y. 99, 409.

SMADEL, J. E. \& WALL, M. J. (1937). Elementary bodies of vaccinia from infected chorio-allantoic membranes of developing chick embryos. J. exp. Med. 66, 325. 
Journal of Gieneral Microbiology, Vol. 20, No. 3

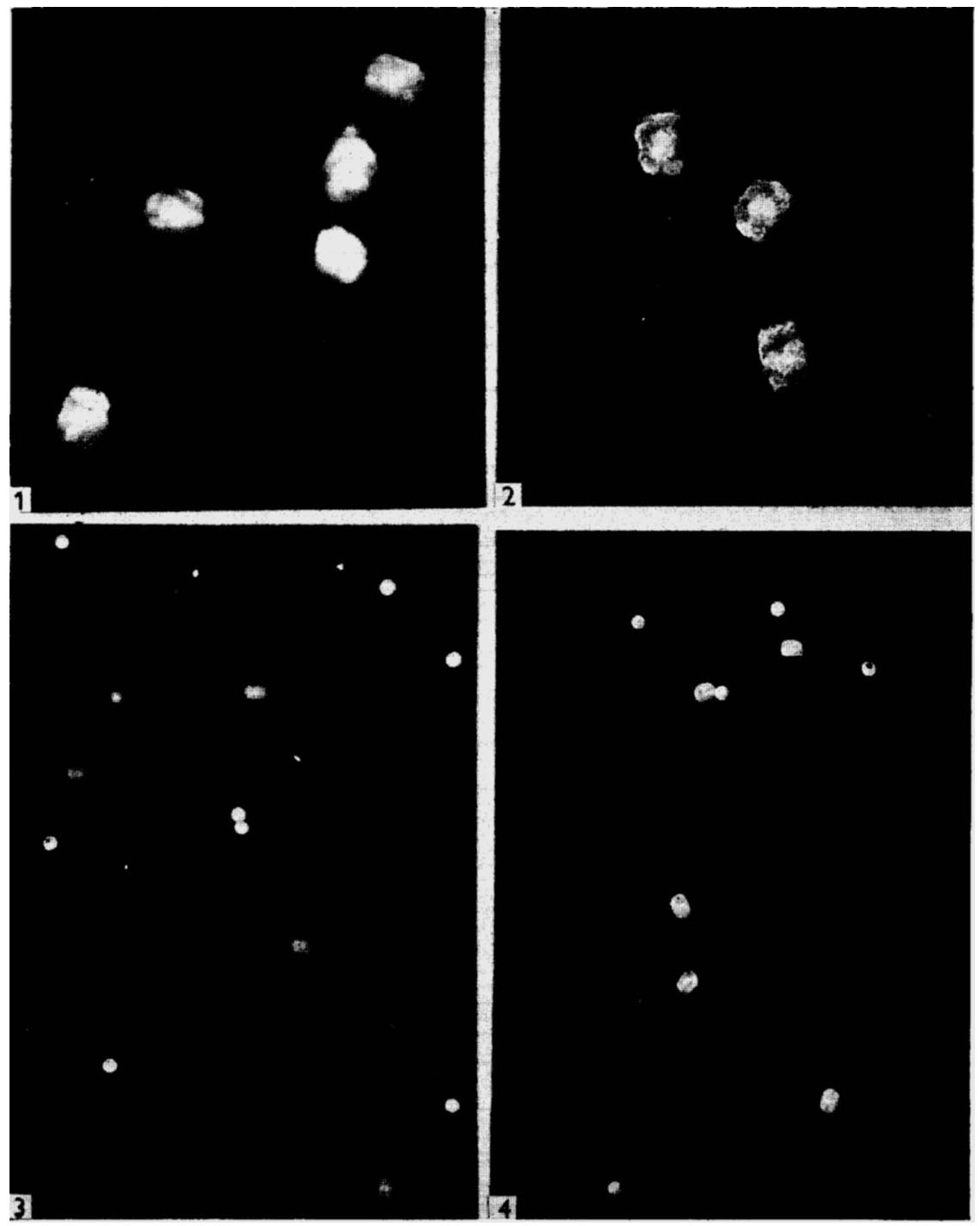

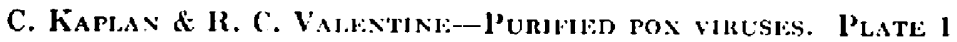

(F'acing p. 61 
Westwood, J. C. N., Phipps, P. H. \& Boulter, E. A. (1957). The titration of vaccinia virus on the chorio-allantoic membrane of the developing chick embryo. J. Hyg., Camb. 55, 123.

Williams, R. C. \& Backus, R. C. (1949). Macromolecular weights determined by direct particle counting. I. The weight of the bushy stunt virus particle. J. Amer. chem. Soc. 71, 4052.

\section{EXPLANATION OF PLATE}

The virus preparations were fixed in $2 \%$ formaldehyde. Electron micrographs were taken after lightly shadowing the specimens with platinum.

Fig. 1. Partially purified vaccinia virus showing the fuzzy appearance caused by soluble impurities. $\times 50,000$.

Fig. 2. Virus purified further by salt floceulation. There is less extraneous material and the particles are more sharply defined. $\times \mathbf{5 0 , 0 0 0}$.

Fig. 3. Virus from tissue culture. Part of a spray droplet used in making the virus particle count. Despite some contamination with cell debris the count of this area is clearly 4 virus and 8 latex particles. $\times 19,000$.

Fig. 4. Virus from rabbit dermis. Part of a spray droplet showing 5 virus and 5 latex particles. There is little debris. $\times \mathbf{1 9 , 0 0 0}$.

(Received 1 December 1958) 